〜55ㅇ，これをハィドロキノンとヂメチル硫酸とより合成した㵵 品との混稜に依りヂメトキシベンゾールなることを確認した。

アニンールの生成 パラアニシヂン (市販品) $50 \mathrm{~g}$ を上と同柡

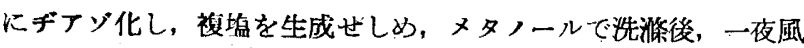
乾した。複塩は渠つたままで $95 \mathrm{~g}$ 。これを今回は磁製ビーカーを 用いずに鉄㱔オートクレーブ中にちがに仕込み $80 \sim 90^{\circ} \mathrm{C}$ で分解 を行5。溫度，压の上界等は鉄を遮断した時と殆んど变らない。 $95^{\circ}$ (9.5 氣厓) まで上る。 5 時間で分解を終了する。分解液をべ ンゾールで抽出した後，实空蒸溜を行う。

$$
\begin{aligned}
& \text { アニソール溜分 } \quad 75 \sim 85^{\circ} / 18 \mathrm{~mm} \quad 15 \mathrm{~g} \\
& \text { ギメトキシベンゾール稀分＼cjkstart殆んどなし } \\
& \text { 高沸溜 分 } \quad 170 \sim 195^{\circ} / 18 \mathrm{mmHg} 3.5 \mathrm{~g}
\end{aligned}
$$

パラメチルアニソールの合成，パラトルイヂン $200 \mathrm{~g}$ を水 700 cc, 濃硫酸 $300 \mathrm{~g}$ に溶かし, 氷冷しつつ $50 \%$ の亞硝酸ソ一发水 溶液を徐々に加えてヂアゾ化する（反応の終点はヨードカリ澱粉 紙で检す)。夯にヂアゾニウム溶液に塩化亞鉛 $180 \mathrm{~g}$ を加え，头 に食壏 $200 \mathrm{~g}$ を加えで゙アゾニウム複塩を析出せしめる。これを 渭别し、ヌッチェ上でメタノールでよく洗涹する。結晶は殆んど 白色で，酒别したままで(濕つたまま) $580 \mathrm{~g}$ を得た。カップリン グに依り純度を湘定すると純度は $89 \%$ であつた。この中その泮
量の $280 \mathrm{~g}$ をメタノール $600 \mathrm{cc}$ 中に加え湯浴中で $40 \sim 60^{\circ} \mathrm{C}$ K 加溫し分解させる。分解最監時は約 40 分でその後更に $60^{\circ} \mathrm{C}$ に 30 分保ち，次に蒸溜に低りメタノールを回收し，残留物を同量の水

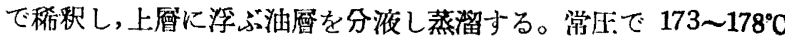
で溜出する溜分を捕集した。收量 $\mathbf{5 5} \mathrm{g}$ 理論量に対する收率はバ ラトルイヂンを基準として $54.2 \%$ である。

上に得られた溜分は酸及びアルカリに不溶で，パラリレゾール とヂメチル碳酸とから得られる パラーメトキシトルオールにその 物理的及び化学的性筫がよく一致する。且つこれを氷醋中でニト 口化して得られた黄色針状のニトロ化合物を精裂すると融点 79.5 〜80 Cを示し,1-オキシ-2,6-ヂニトロトルオールを生成した事か ら，パラーメトキシートルオールなる事を陮認したがこれ等の詳細 は「パラーメトキシトルオールのニトロ化」として別に報告する。

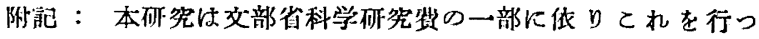
た。能して謝宽を表す。

\section{一引用交献一}

1) Vermeulèn, Requeil travaux chimique, 25, 28.

2) $A m ., 31,24$ (1904).

Ber., 34, 3337; 23, 2995; 28, 2049.

（京都大学工学部工業化学科小时研究室）（昭和 25 年 8 月 28 日受理）

\title{
（117） ナフタリンスルフォン酸塩の蒸氣熱分解に依るナフトールの合成
}

\author{
由良章三・宇 野 虹 兒
}

ベンゾールスルフォン酸ソーダを荷性フルカリ，洞石灰，その 他塩基性物留の共存下に $350 \sim 450^{\circ} \mathrm{C}$ の溫度で水蒸氣で熱分解す ると,遊離の石炭酸の得られる事を著者等は既に報告したが4), こ の場合ベンゾールスルフォン酸ソーダの代りにナフタリンスルフ ナン酸ソーダを使用して,ナフトール類の合成を試みた。

๔ーナフタリンスルフォン酸ソーダの場合には, 同㥞な蒸氣熱分 解に於て脫スルフォン化が起り易く, 消石灰, ソーダ灰, その他 の弱塬基性塩の共存で $350 \sim 480^{\circ} \mathrm{C}$ で熱分解する時は主生成物は ナフタリンであつた。前性ソーダの如き强ソルカリの共存に依り 初めて あ起ク，ナフタリンが著境生成した。

ß-ナフタリンスルフォン酸ソーダの場合にむ $\alpha$-スルフォン酸 の場合と同樣に脫スルフォン化反応を澼ける事は出來ないか， $\alpha-$ スルフォン酸の場合に比較すれば,ナフトールの生成量は租々多 い。

\section{実 驗 の 部}

試料 $\alpha$-ナフタリンスルフォン酸ソーダ及び $\beta$-ナフタリンス ルフォン酸ソーダはそれぞれ常法に從いナフタリンを低溫1及び 高濞2)でスルフォン化して調製した。

実驗方法 アルカリの添加はナフタリンスルフォン酸熄に対し 苛性ソ一ダの場合は当䭪を, 文消石灰の場合には石炭酸合成の場
合の最適比, 郎ち重量比で $2: 3$ の消石灰を用いた。蒸釆吹込溫 度はすべて $350^{\circ} \mathrm{C}$ とし, 反広の最後には $480^{\circ} \mathrm{C}$ まで高めた。反 応裝置はベンゾールスルフォン酸ソーダの蒸氣熱分解の場合4)と 同一物を用いた。但し熱分解して水蒸氣ととあに溜出して來る溜 出物の冷却には, 空氣冷却器として直径 $2 \mathrm{~cm}$, 長さ $1 \mathrm{~m}$ のガラ ス管を使用し溜出物に依り冷却器の閉塞寸る事と, 副生ナフタリ ンの逃散とを避けた。

溜出物の処理は溜出物全体に $30 \%$ 些性ソーダ溶液 $20 \mathrm{cc}$ を扣 之加溫してナフトールを溶解し, 冷却後谒過した。「ルカリ不溶 分は褐色乃至黑褐兒を呈し，主としてナ゙フタリンである。漬液を 塩酸で中和し, 次いでリトマス酸性にすると, ナフトールは直ち に沈澱して來る。これを氷冷渴别して乾燥する。

\section{実 驗 結 果}

I. $\beta$-ナフタリンスルフォン酸ソーダの熱分解 $\beta$ タ-ナフタリン スルフォン酸ソーダと菏性ソーダの混合物を釜中に仕込み加熱し て $300^{\circ}$ 乃至 $350^{\circ} \mathrm{C}$ で蒸氣を收き込むと直ちにナフタリンと思わ れる白熛と黑褐色油状物とか溜出して來る。これ等は冷却管の中 途で冷却固化して前者は白色, 後者は黄褐乃至赤褐色の固体とな る。 $470{ }^{\circ} \mathrm{C}$ 以上になるとガス状分解物が溜出ずる。反応は 80〜 100 分で終る。反応釜の㩭汼は終始容易であるが，時々蒸氣貲出 孔の閶塞が起つた。 
嶈性ソーダの代りに消石灰を用いた場合, 蒸录收込後の経過は 苛性ソーダ添加の場合と殆んど同樣であるが，480 白焐（ガス狀分解物）を生じない。時々蒸氣皟出孔の閉塞が起つ

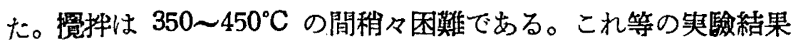
を第 1表に総括した。生成した粗 $\beta$ ーナフトールはそのままで晍 点113.5 115 ${ }^{\circ} \mathrm{C}$ であるが,水から再結晶すると融点 $122.5 \sim 123^{\circ} \mathrm{C}$ を示し，標品との混融に依り $\beta$ ーナフトールなる事を確認した。 スアルカリ不溶分はこれを直室蒸溜に依り精製し，混踤に依りナ フタリンである事を碓認した。

夾に の量を变化して生成ナフトールに及塱響を检へた。それ等の 結果を第 2 表に示す。使用した $\beta$-ナフタリンスルフォン酸ソー 多は水分 $18.4 \%$ 及び挴析の際の食壏を $10.3 \%$ 含有していたの で，これ等を差し引き純スルフォン酸ソーダを基礎として生成ナ フトールの理論値に対する收率を計算した。

$$
\text { 第 } 1 \text { 表 }
$$

\begin{tabular}{|c|c|c|c|c|c|c|c|c|}
\hline $\begin{array}{l}\text { 笑 } \\
\text { 騕 } \\
\text { 悉 } \\
\text { 号 }\end{array}$ & 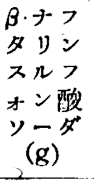 & $\begin{array}{r}\text { アルカ } \\
\text { (g) }\end{array}$ & & $\begin{array}{l}\text { 溫 度 } \\
\left({ }^{\circ} \mathrm{C}\right)\end{array}$ & $\begin{array}{l}\text { 時 閐 } \\
\text { (分) }\end{array}$ & $\overbrace{(\mathrm{g})}^{\substack{\text { 粗 } \beta \\
\Gamma-}}$ & $\overbrace{\begin{array}{c}\text { \%(対理 } \\
\text { 論值) }\end{array}}^{\text {・・フ }}$ & $\begin{array}{c}J \\
7 \\
タ \\
y \\
2 \\
(g)\end{array}$ \\
\hline 1 & 150 & $\mathrm{NaOH}$ & 30 & $300 \sim 480$ & 70 & 6.0 & 6.4 & - \\
\hline 2 & 100 & $\mathrm{NaOH}$ & 20 & $300 \sim 480$ & 120 & 2.8 & 4.4 & 4.0 \\
\hline 3 & 100. & $\mathrm{NaOH}$ & 20 & $350 \sim 480$ & 100 & 7.8 & 12.5 & 13.5 \\
\hline 4 & 100 & $\mathrm{NaOH}$ & 20 & 同上 & 同上 & 10.1 & 16.1 & 18.0 \\
\hline 5 & 100 & $\mathrm{Ca}(\mathrm{OH})_{2}$ & 150 & 同上 & 同上 & 5.0 & 8.0 & 5.0 \\
\hline 6 & 100 & $\mathrm{Ca}(\mathrm{OH})_{2}$ & 150 & 同上 & 同上 & 3.1 & 5.0 & 7.0 \\
\hline
\end{tabular}

\begin{tabular}{|c|c|c|c|c|c|c|c|}
\hline 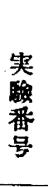 & $\begin{array}{c}\beta \cdot \text { ンタ } \\
\text { リンスル } \\
\text { フォン酸 } \\
\text { ソーダ } \\
\text { (g) }\end{array}$ & $\begin{array}{c}\mathrm{NaOH} \\
\text { (g) }\end{array}$ & $\begin{array}{c}2 \\
\text { 溫 度 } \\
\left({ }^{\circ} \mathrm{C}\right)\end{array}$ & 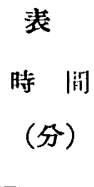 & & 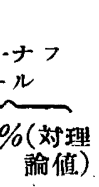 & $\begin{array}{l}\text { ナフ } \\
\text { タ 1 } \\
2 \\
\text { (g) }\end{array}$ \\
\hline 11 & 150 & 10 & $300 \sim 460$ & 90 & 13.0 & 19.4 & 22.0 \\
\hline 12 & "I & 20 & $300 \sim 480$ & 60 & 3.0 & 4.5 & 17.0 \\
\hline 13 & "I & 30 & $300 \sim 480$ & 70 & 9.0 & 13.4 & 12.0 \\
\hline 14 & "I & 30 & $250 \sim 400$ & 80 & 13.0 & 19.4 & 11.0 \\
\hline 15 & "I & 40 & $300 \sim 480$ & 60 & 7.0 & 10.5 & 8.0 \\
\hline 16 & "I & 50 & $300 \sim 450$ & 80 & 8.0 & 11.9 & 2.0 \\
\hline 17 & "I & 60 & $300 \sim 450$ & 70 & 2.0 & 3.0 & 3.5 \\
\hline
\end{tabular}

以上第 1 ,第 2 表の結果から，消石灰添加の場合でも約 $8 \%$ (対 理論值）程度の $\beta$ ーナフトールが生成するが，㩭汼の困難, 泥狀反 応混合物の冷却管への突潄等, 反応操作は種々な困難が伴い, 同 一低件でもナフトール收量は一定しない”。更た反応集置の改善工 夫を必要とする。苛性ソーダを添加した場合にはこれ等操作上の 困難は比校的少いが，生成ナフトールを水蒸氣に依り速かに反応 系外に溜出し去る事は石炭酸の場合に比較して困難であり，從つ て收率も低い。苛性ソーダをナフタリンスルフォン酸ソーダに対

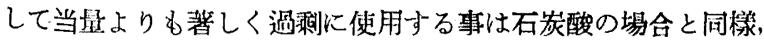
却つてナフトールの收得基を娍じる。ナフタリンスルフォン酸》 一ダの脫スルフォン化に依るナフタリンの生成は, 跒性ソーダの
添加量に略々逆比例し，テルカリの添加のない場合は殆んどナフ タリンのみを生成する。

II. $\alpha$-ナフタリンスルフォン酸ソーダの热分解 $\boldsymbol{\beta}$-ナフタリ ンスルフォン酸ソーダの場合と大体同樣な反応経過をたどるが, 第 3 表に示寸如く收率は $\beta$ ースルフォン酸ソーダの場合上り更に 低い。得られた粗 $\alpha$-ナフトールはそのまをで融点 $60 \sim 66^{\circ} \mathrm{C}$, こ れを水より再結晶すると融点 $84.5 \sim 85.5^{\circ} \mathrm{C}$ となつた。これは $\alpha-$

\begin{tabular}{|c|c|c|c|c|c|c|c|}
\hline $\begin{array}{l}\text { 头 } \\
\text { 輹 } \\
\text { 番 } \\
\text { 豆 }\end{array}$ & $\begin{array}{c}\alpha \text { ナフタ } \\
\text { リンスル } \\
フ \text { オン酸 } \\
\text { ソーダ } \\
\text { (g) }\end{array}$ & $\begin{array}{r}\text { アルカ } \\
\text { (g) }\end{array}$ & 第 & $\begin{array}{c}3 \text { 表 } \\
\text { 溫 度 } \\
\left({ }^{\circ} \mathrm{C}\right)\end{array}$ & $\begin{array}{l}\text { 時 间 } \\
\text { (分) }\end{array}$ & 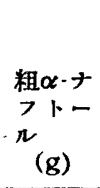 & $\begin{array}{l}\text { ナフ } \\
\text { タ } 1 \\
\text { ン } \\
\text { (g) }\end{array}$ \\
\hline 21 & 150 & $\mathrm{NaOH}$ & 30 & $350 \sim 480$ & 80 & 5.0 & 7.0 \\
\hline 22 & 150 & $\mathrm{NaOH}$ & 30 & 同上 & 80 & 3.4 & 10.2 \\
\hline 23 & 150 & $\mathrm{NaOH}$ & 30 & 同上 & 90 & 2.5 & 9.0 \\
\hline 24 & 100 & $\mathrm{Ca}(\mathrm{OH})$ & 150 & 同上 & 80 & 2.4 & 5.0 \\
\hline
\end{tabular}

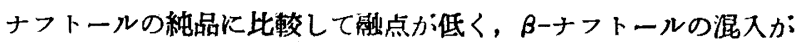
考えられたので，一部試料をとり，醌酸酸性溶液中でヂアゾニウ ム化合物で滴定して ${ }^{3)} \alpha$-ナフトールの含有量を求めた結果 約 $\left\{\begin{array}{ll}\alpha \text {-ナフトール } & 85 \% \\ \beta \text {-ナフトール } & 15 \%\end{array}\right\}$ と云5結果を得た。。

III. $\beta$-ナフトールを用いてのブランクテスト ナフタリンス ルフォン酸ソーダの蒸釆熱分解に依るナフトールの收率の低いこ とが，專ら熱分解が円滑に進行しないためであるか, 更に丈, 反 応裝置の不備なことも原因しているのではないかと云う事を確め るため, ナフタリンスルフォン酸ソーダの代りに を熱分解鍫にアルカリと混合して仕込々同條件で蒸氣を吹き込み 使用したナフトールの中どれだけ溜出して回收し得るかを检し た。その結果は第 4 表に示す如く，使用したナフトールの約 $20 \%$

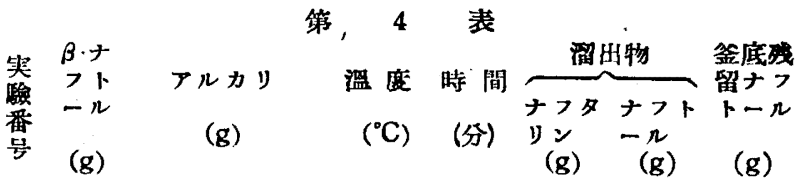

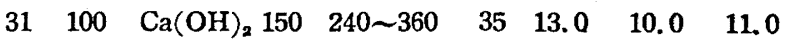

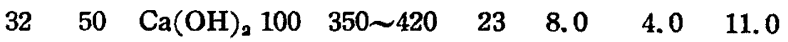
$\begin{array}{lllllllll}33 & 50 & \mathrm{NaOH} & 15 & 350 \sim 480 & 100 & 2.0 & 10.0 & -\end{array}$ 回收されたに過ぎない。これをスルフォン酸ソーダに換算すれば 大体ナ゙フタリンスルフォン酸ソーダに対して約 $10 \%$ 重量のナフ トールと云う事になり， $\beta$ ースルフォン酸の熱分解の場合と大差の ない結果となり， $\beta$ ーナフタリンスルフォン酸ソーダの熱分解の場 合には, 反底詃置及び過熱水蒸氣の吹込等に就て一段の工夫が必 要である事を示している。

\section{一引用文献一}

1) $\alpha$ ーナフタリンスルフォン酸ソーダ, F. David, Grundlegende Operationen der Farben Chemie, 159 頁.

2) $\beta$ ーナフタリンスルフォン酸ソーダ, F. David, Grundlegende Operationen der Farden Chemie, 133 頁.

3) ナフトールの定量法, 同上, 320 頁.

4) 的良,宇野, 工化, 50,136, 137 (1947)；51，160 (1948). 